\title{
William J. Baumol: An Entrepreneurial Economist on the Economics of Entrepreneurship*
}

\author{
by \\ Gunnar Eliasson ${ }^{1}$ and Magnus Henrekson ${ }^{2}$ \\ SSE/EFI Working Paper Series in Economics and Finance No 532 \\ August 22, 2003
}

\begin{abstract}
William J. Baumol is the 2003 winner of the International Award for Entrepreneurship and Small Business Research. Throughout his career Baumol has urged the profession to pay attention to the instrumental role of entrepreneurship in economic renewal and growth. At the same time he has insisted that economists continue to use their usual tool box when the purview of analysis is extended to entrepreneurship. Hence, Baumol can be characterized as a revolutionary from within. In this article we present and discuss Baumol's research contribution in the areas of entrepreneurship and small business economics, notably from a growth perspective. In addition to placing his work in these areas into the wider context of his full contribution, we emphasize Baumol's findings that growth cannot be explained by the accumulation of various factors of production per se; human creativity and productive entrepreneurship are needed to combine the inputs in profitable ways. As a result, an institutional environment that encourages productive entrepreneurship and human experimentation becomes the ultimate determinant of economic growth.
\end{abstract}

Keywords: Economic development; Entrepreneurship; Small business economics.

JEL Codes: B49; B52; B53; O31.

${ }^{1}$ Department of Industrial Economics and Management

Royal Institute of Technology (KTH)

SE-100 44 Stockholm

Phone: +46-8- 7906803

Fax: +46-8- 6226914

e-mail: Gunnar.Elias@telia.com
${ }^{2}$ Department of Economics

Stockholm School of Economics

P. O. Box 6501

SE-113 83 Stockholm

Phone: +46-8-736 9202

Fax: +46-8-313207

e-mail: Magnus.henrekson@hhs.se

\footnotetext{
* The authors of this article are chairman and member, respectively, of the Prize Committee for The International Award for Entrepreneurship and Small Business Research. The Prize is awarded by the Swedish Foundation for Small Business Research (FSF) and the Swedish Board of Industrial and Technical Development (NUTEK). An important aim with this prize is to attract broader attention to this research field. A precondition for choosing the winner of the award is that the research for which the award has been granted is a significant contribution to the theory and empirical understanding of entrepreneurship and the importance of entrepreneurship, new firm formation and small businesses in economic development. Apart from the honor the Prize consists of USD 50,000. It has been awarded annually since 1996. Previous winners include Zoltan Acs, Howard Aldrich, David Audretsch, and David Storey. More information about the Prize and previous winners is available at http://www.fsf.se/intaward.html.
} 


\section{Introduction}

The Swedish Foundation for Small Business Research (FSF) and the Swedish Board of Industrial and Technical Development (NUTEK) has given its 2003 International Award for Entrepreneurship and Small Business Research to William J. Baumol. In this article we present and evaluates the contributions of the Prize winner to the economics of entrepreneurship and economic growth.

As a general theorist William J. Baumol has a long and outstanding record of addressing the real problems of our world. His career is now well into its sixth decade, but new insights still keep pouring out of his prolific pen. Although basically neoclassical, Baumol's ambition has been to extend mainstream economics to be compatible with a wider range of theoretical assumptions and economic phenomena than the received model is capable of addressing in a relevant way. In doing so Baumol has constantly built new bridges that link theory, policy and practice. In many ways Baumol can be seen as a revolutionary from within in that he masters the tools of the trade and insists that they be used, as far as possible, to address real-life problems of great urgency.

In fact, Baumol himself has been an entrepreneur in the markets for economic science, and it is only logical that Baumol was among the first to urge his fellow mainstreamers in a 1968 American Economic Review article to start paying attention to the role of entrepreneurship in economic development, or to repeat his now famous words (p. 68): "The theoretical firm is entrepreneurless - the Prince of Denmark has been expunged from the discussion of Hamlet."

\section{Baumol's Research Agenda - An Overview}

Baumols's research on firm behavior and entrepreneurship is part of a broadly defined research agenda in economics, ranging from traditional neoclassical analysis (1961), an early bold attempt at economic dynamics (1951), and welfare economics and the theory of the state (1952), a revised version of his doctoral thesis from the University of London (1949), to the analysis of firm behavior (1959, 1971 [with Stewart]). The idea that firms may be sales maximizers rather than profit maximizers is also attributable to Baumol (1959). Above all, 
Baumol's entire research agenda has been inspired by the ambition to put life - not least entrepreneurial life - into economic theory, albeit, preferably without departing from the axiomatic foundation of the mainstream model. However, to make room for the Schumpeterian entrepreneur in economic theory is no easy task, perhaps it is infeasible, as Baumol admitted already in his seminal article on the subject.

Baumol's writing on business behavior and the economics of the firm is enormous and highly suggestive. It extends from traditional microeconomics, the behavioral theory of the firm (1971 [with Stewart]), and the use of rules of thumb in imperfect markets (1964 [with Quandt]) to his highly innovative work on the economics of the performing arts (1966 [with Bowen]), notably the Athenian Drama (1971) and the stimulating inquiry into the theater of renaissance London (1972 [with Oates]). The fundamental idea underlying this analysis was generalized in an article in the American Economic Review in 1967. This is probably his most cited work. There he shows that an economy with one industry with a potential for rapid longterm productivity growth (such as the engineering industry) and one sector (such as care of the elderly or the performing arts) which cannot increase productivity to any significant extent will experience an indefinite increase in the relative price of the output from the nonprogressive sector. One of two things will then happen: the real consumption of output from the nonprogresive sector will decrease strongly over time or its share of total expenditure will increase. This phenomenon is now generally referred to as Baumol's Cost Disease, and its manifestations are apparent everywhere in the modern economy with cost crises in the public labor-intensive sector and enormous relative price increases for nonsubsidized opera performances, haute cuisine restaurants et cetera. This analysis coincides with, and resembles the problems of the nontraded goods sector discussed in the socalled EFO report in Sweden, first presented in 1968 (Edgren, Faxen and Odhner, 1973).

\section{On the Role of the Entrepreneur}

Baumol's work on the entrepreneur should be seen in the wider context of his analysis of firm behavior and of the economy at large. His analysis of the entrepreneur, in turn, has been guided by two principles that he formulated very early in his career: 
1. Make your assumptions confer with reality as much as you can (1948), but not to the extent that you cannot say anything. Therefore, it becomes necessary, he argues, to economize on the introduction of realism into analysis (1959, p. 4).

2. If possible, try to stay within the framework of neoclassical analysis.

In attempting to introduce the live entrepreneur into mainstream analysis Baumol has tackled these problems head on. Six publications should be particularly highlighted in this context:

1968

1978 (with Fischer)

1982 (with Panzar and Willig)

1990

1993

2002
"Entrepreneurship in Economic Theory"

"Cost-Minimizing Number of Firms and Determination of Industry Structure"

Contestable Markets and the Theory of Industry Structure

"Entrepreneurship: Productive, Unproductive and Destructive"

Entrepreneurship, Management and the Structure of Payoffs

The Free-Market Innovation Machine - Analyzing the Growth Miracle of Capitalism

Baumol (1968) examines the role of the entrepreneur from three different angles:

(a) Why should we be concerned? Answer: Because entrepreneurship is a critical factor behind economic development.

(b) Why has economic theory failed to develop a formal analysis of entrepreneurship and why is this unlikely to change in the foreseeable future? Answer: Because using the calculus to present the entrepreneur as an automaton maximizer leads nowhere in the analysis of entrepreneurship. There is little hope that mainstream economics will abandon that approach in the near future, he continues (p. 68): "The terminology of game theory has been extremely suggestive; the willingness of the behaviorists to break away from traditional formulations has been encouraging; but I see no real breakthroughs in this area even on the distant horizon."

\footnotetext{
${ }^{1}$ There have been several attempts in recent years to include entrepreneurship in neoclassical growth models without disrupting their underlying axiomatic foundation; see, e.g., Aghion and Howitt (1992), Helpman (1992), and Holmes and Schmitz (2001). However, entrepreneurship has invariably been defined narrowly and has not in any way captured the wide-ranging and complex functions of the entrepreneur suggested outside mainstream economics (see, e.g., Glancey and McQuaid, 2000 and Swedberg, 2000).

${ }^{2}$ Johansson (2003) confirms that the entrepreneur is still largely absent from postgraduate training in economics. In a systematic review of all graduate textbooks used in micro, macro and industrial organization courses at Swedish graduate programs in 2002, he does not find a single reference to the entrepreneur or entrepreneurship.
} 
(c) Why is it possible to say a great deal on the role of entrepreneurship even without a rigorous analysis of the behavior of the entrepreneur and the supply of entrepreneurship? Answer: Economic theory is focused on the use of inputs and tells us "little about where they come from" (p. 69), since inputs are assumed to be exogenous. So trying to introduce the entrepreneur in mainstream economic theory means changing theory in a fundamental sense. But one way out would be to look instead at the payoff to the entrepreneur; for instance, if he or she undertakes R\&D investments, how does the tax system affect the incentives to commercially exploit the new knowledge gained?

The ideas outlined in his 1968 article have guided Baumol's research on entrepreneurship since then. Despite his skepticism about the possibilities of rigorously modeling the entrepreneur in the context of mainstream economic theory, Baumol launched a grand project in the late 1970 s to integrate entrepreneurial activity into the standard economic model. His theory (1982 [with Panzar and Willig]) of contestable markets was sold heavily and provocatively as an "uprising in the theory of industry structure" and with such vigor that the profession took offense (see, inter alia, Schwarz and Reynolds, 1983). This analysis (1982, p. 2) "provides a generalization of the concept of the perfectly competitive market" to one which Baumol, Panzar and Willig called a "perfectly contestable market" which was disciplined by potential competition from new entrants. Their main point, argued already in Baumol's theoretical 1978 article (with Fischer), was that industry structure is now endogenously explained, not exogenously given. Furthermore, they claimed to show that a perfectly contestable equilibrium can exist for a very small number of firms, even under economies of scale. Contestable market theory replaces the price-taking assumption of perfect competition theory with rapid entry and exit. Free and perfectly reversible entry and costless exit provided the potential competition needed to achieve that. The theory, however, implied that not much actual entry or exit could take place. Critics were also fast to point out that many of the assumptions were not empirically relevant, and that a threat of entry is not credible if significant entry does not take place (Spence, 1983; Shepherd, 1984).

One theoretical spinoff from contestable market theory touched upon in the 1982 book and article and returned to in a much later article by Audretsch, Baumol and Burke (2001) was a new approach to competition policy. By facilitating and stimulating innovative firm entry, notably through reducing barriers to entry, policymakers may have a potent instrument to 
prevent monopoly formation through enhanced competition. This substitutes for the "trustbusting" regulator that emerges as the preferred method from mainstream static theory. This argument is, however, not entirely new. Already Adam Smith regarded freedom of entry as the most relevant indicator of competition and of the efficiency of the self-regulating system of the market, a system that was primarily disturbed, in his view, by "monopoly produced by government regulation" (Anderson and Tollison, 1982).

\section{Can Static Equilibrium Be Saved?}

Entrepreneurship and firm turnover play critical roles in economic dynamics and endogenous growth. Baumol et al. (1982) took a bold step forward with contestable market theory. They replaced the price-taking assumption of the perfect competition model with perfect entry and exit. They were, however, securely fastened to the exogenous static equilibrium framework by a safety line. In fact, competitive entry was a threat defined such that the exogenous equilibrium properties could be retained. Here Baumol was true to his early (1968) "recommendation" that you stay as long as possible within the neoclassical framework. However, this had the unfortunate consequence that critics could say that contestable market theory contributed to our understanding of important economic phenomena, but that it was not a radically new "uprising" in economic theory. The key problem with the contestability model was that significant realized costly entry and exit and strategic behavior of firms tended to upset the conditions necessary for the attainment of exogenous equilibrium.

The key feature of the neoclassical model that distinguishes it from the alternative schools of economic thought is the existence of an exogenous equilibrium and a well-defined solution to the resource allocation problem (Rosen, 1997). Models in the Austrian and Schumpeterian tradition do not impose such conditions. Hence, they constitute the appropriate reference point to compare with the neoclassical model when it comes to defining a relevant entrepreneur and his/her role in the process of economic development.

The general question to raise here, therefore, is whether the entrepreneur can at all be endogenized in an empirically meaningful way, as Baumol hoped, within the static exogenous equilibrium framework (Barreto, 1989; Eliasson, 1984), or rather if we can model the entrepreneur as we would realistically like to see him or her within that theoretical 
framework. The general equilibrium model is a powerful analytical tool, unique to economics in the social sciences. But powerful analytical tools narrow the range of phenomena that can exist (within the model) and, hence limit understanding to that restricted set of phenomena. You will have to go outside the analytical model to understand, something Carl Menger (1871) regarded as unavoidable for Verstehen.

Static equilibrium models have great difficulties dealing with the strategic behavior of agents that we tend to associate with entry and exit and monopolistic competition. Already Knut Wicksell (1923) remarked, when discussing a bold attempt by the young Swedish economist Gustav Åkerman $(1921,1923)$ to "model" simultaneous production and price setting behavior using verbal reasoning and simple "High School" mathematics, that normally you hold structures and distribution constant when studying price-setting behavior, and prices constant when studying production change. When you have carried out the two partial analyses you may try to model simultaneous price and quantity setting. Apparently Wicksell, being also a mathematician, thought it could be done within the exogenous equilibrium framework, and thus would have sided with Baumol.

The experience of many, including the neo-Keynesians, however, is that this is no easy task. Increased realism implies the loss of the powerful tool of calculus and game theory and there may be no well-defined solution to the resource allocation problem. Rosen (1997) is skeptical. The entrepreneur, even though probably of critical importance for growth, "lacks operational definition" and is too "elusive" a concept to ever fit into the neoclassical model. While Rosen (1997) is no friend of ad hoc entrepreneurship theory without an explicit market context, he believes that "neoclassical economics undoubtedly would be enriched by a more fully articulated view of competition as a selection device ... and generator of economic change," the elusive entrepreneur being understood as the driver of competition. Even though Baumol is not quoted in Rosen's article, the two appear to agree on this count and to be implicitly skeptical of much of neo-Schumpeterian theorizing lacking a well-defined economic context.

Quite understandably then, few attempts have been made since Baumol's 1968 paper to make neoclassical theory more entrepreneurial, and those efforts have amounted to little more than using an entrepreneurial terminology, and, therefore, have not yet taken us much further. Here we agree with Baumol (2000) that simulation offers new opportunities to study complex 
disequilibrium economics and that even though simulation of disequilibrium models does not provide fully general and representative results, "for example" is a powerful method to empirically disprove results based on analytical models. Even though the exogenous equilibrium conventionally defined will probably have to be abandoned if we introduce a relevant entrepreneur in the neoclassical model, such considerations suggest that we should be able to redefine the concept of equilibrium to make it compatible with the dynamics of a model of an entrepreneurial economy (Eliasson, 1991).

\section{Institutions and Incentives Direct Economic Change}

Baumol's 1990 article in the Journal of Political Economy specifically deals with the effect of institutions/the social payoff structure on the distribution of entrepreneurship between productive and unproductive/destructive activities. He assumes that the supply of entrepreneurship, i.e., the application of entrepreneurial talent, is roughly a constant, while its distribution between productive and unproductive or even destructive activities is greatly affected by the social payoff structure. He tests this proposition in an exploratory fashion on highly varying historical contexts such as Ancient Rome, China under the Sung Dynasty and the UK in the Late Middle Ages, and asks what were the institutions that allowed the UK to embark on a sustainable growth process lasting for centuries, while the technologically advanced China economy remained stagnant. Baumol's broad historical analysis strongly suggests that the factors that "forge the structure of payoffs" for entrepreneurship are manyfaceted, but that they are nevertheless a central part of the explanation.

The idea in the 1990 article is taken several steps further in Baumol's 1993 book Entrepreneurship, Management and the Structure of Payoffs. In addition to the broad historical analysis a number of new applications of the basic idea are presented. Among other things he discusses the role of entrepreneurship in corporate takeovers and litigation and how the rules of the game should be designed so that wasteful rent-seeking behavior is avoided. Some first-generation analytical models are also suggested. The model presented in the epilogue is designed to capture the fact that variables such as education and investment, customarily assumed to be exogenous in conventional growth analysis, are really endogenous variables. Investment and education largely take place as a response to growth, while the ultimate cause of growth (North, 1990) is the level of productive entrepreneurial activity. 
Baumol's most recent book The Free-Market Innovation Machine - Analyzing the Growth Miracle of Capitalism, published in 2002, examines the capacity of the free-market economy "to produce a stream of applied innovations" and a rapid rate of growth. This book challenges yet another type of received wisdom in mainstream economics, namely that price competition is a prime driver of economic growth. Instead he stresses the combined and highly powerful effect of entrepreneurial innovation and routine/systematic innovation in incumbent firms, in particular the large firms in oligopolized industries. Thus, for the leading firms in capitalist economies not price but product innovation becomes the major means by which firms stay competitive. This characteristic of industrial dynamics, Baumol argues, has turned the freemarket economy into such a successful growth machine.

Baumol's prize lecture, given at the Stockholm School of Economics on May 22, 2003, was entitled "The Role of Large and Small Firms in Innovation: The David and Goliath Symbiosis". In that lecture he synthesized the insights from the 1993 and 2002 books. The lecture was a beautiful demonstration of Baumol's far-reaching erudition and extraordinary ability to improve our understanding of the big issues. Still, the main message can be easily summarized. Capitalism is unrivalled when it comes to innovation and economic growth. This achievement presupposes both the individual entrepreneur and the large oligopolistic firm. With few exceptions major innovations emanate from the ingenuity and serendipity of individual entrepreneurs (Scherer, 1980), but in order to transform the original innovation into a full-scale innovation that sizably enhances productivity and welfare large firms become crucial. Their routinized step-by-step improvements of the original concept is necessary to reap the full benefits of the capitalistic organization of the economy. In fact, for the large firms in high-tech industries innovation is a matter of long-run survival. There is a continuous "arms race" involving all the large firms and in order not to lose ground to its competitors each firm is forced to continue to expend resources on R\&D.

\section{Concluding Remarks}

The accumulation of factors of production per se - be they knowledge, physical or human capital - cannot alone explain economic development. They are necessary inputs in 
production, but they are not in themselves sufficient for economic growth to occur. Economists, however, thought so for a long time and in centrally planned economies and many third world countries massive investments in human and physical capital did not produce much prosperity. Human creativity and productive entrepreneurship are needed to combine these inputs in profitable ways, and hence an institutional environment that encourages free entrepreneurship becomes the ultimate determinant of economic growth. ${ }^{3}$ Thus, the entrepreneur and entrepreneurship should take center stage in any effort to explain long-term economic development.

William Baumol has now urged the profession for at least 35 years to give the entrepreneur a central role also in mainstream theorizing. Whether the complexity of the entrepreneurial function can eventually be modeled so that it becomes a key actor in the mainstream model, and not just in the real world, remains to be seen. But whatever the outcome, the urge of one of the most highly respected mainstream economists of his generation will never lose its relevance. A body of economic theory that fails to deal with what is likely to be the most important factor for growth and renewal - individuals pursuing entrepreneurial opportunities - will always be blatantly incomplete.

\section{References}

Aghion, Philippe and Peter Howitt, 1992. "A Model of Growth through Creative Destruction." Econometrica 60 (2), 323-351.

Anderson, Gary M. and Robert D. Tollison, 1982, "Adam Smith's Analysis of Joint-Stock Companies." Journal of Political Economy 90 (6), 1237-1256.

Audretsch, David B., William J. Baumol and Andrew E. Burke, 2001 "Competition Policy in Dynamic Markets." International Journal of Industrial Organization 19 (3), 613-634

Barreto, Humberto, 1989, The Entrepreneur in Economic Theory. London and New York: Routledge.

Baumol, William J., 1948. ”Notes on Some Dynamic Models." Economic Journal 58 (232), 506-521.

Baumol, William J., 1951. Economic Dynamics. New York: Macmillan.

Baumol, William J., 1952. Welfare Economics and the Theory of the State. London School of Economics and Political Science: Longmans, Green.

Baumol, William J., 1959. Business Behavior, Value and Growth. New York: Macmillan.

Baumol, William J., 1961. Economic Theory and Operations Analysis. New York: Prentice Hall.

Baumol, William J. and William Bowen, 1966. Performing Arts: The Economic Dilemma. New York: The Twentieth Century Fund.

Baumol, William J., 1967. "Macroeconomics of Unbalanced Growth: The Anatomy of Urban Crisis." American Economic Review 57 (2), 415-426.

\footnotetext{
${ }^{3}$ See, e.g., Holcombe (1997) and Henrekson and Rosenberg (2001) for an elaboration on this point.
} 
Baumol, William J., 1968, "Entrepreneurship in Economic Theory.” American Economic Review 58 (2), 64-71

Baumol, William J., 1971. Economics of the Athenian Drama." Quarterly Journal of Economics 85 (3), 365376.

Baumol, William J., 1972. "On the Economics of the Theatre in Renaissance London.” Swedish Journal of Economics 74 (1), 136-160.

Baumol, William J., 1982. "Contestable Markets: An Uprising in the Theory of Industry Structure." American Economic Review 72 (1), 1-15.

Baumol, William J., 1986. "Williamson's The Economic Institutions of Capitalism." Rand Journal of Economics 17(2), 279-286.

Baumol, William J., 1987. On Formal Dynamics: From Lundberg to Chaos Analysis. Unpublished manuscript, July.

Baumol, William J., 1990, "Entrepreneurship: Productive, Unproductive and Destructive." Journal of Political Economy 98 (5), 893-921.

Baumol, William J., 1993. Entrepreneurship, Management and the Structure of Payoffs. Cambridge, MA: MIT Press.

Baumol, William, J., 2000, Review: Out of equilibrium, Structural Change and Economic Dynamics 11: 227-233.

Baumol, William J., 2002. The Free-Market Innovation Machine-Analyzing the Growth Miracle of Capitalism. Princeton and Oxford: Princeton University Press.

Baumol, William J. and Dietrich Fischer, 1978. "Cost-Minimizing Number of Firms and Determination of Industry Structure." Quarterly Journal of Economics 92 (3), 439-468.

Baumol, William J., John C. Panzar and Robert D. Willig, 1982. Contestable Markets and the Theory of Industry Structure. San Diego: Harcourt Brace Jovanovich.

Baumol, William J., John C. Panzar and Robert D. Willig, 1983. "Contestable Markets: An Uprising in the Theory of Industry Structure: Reply." American Economic Review 73 (3), 492-496.

Baumol, William J. and Richard E. Quandt, 1964. "Rules of Thumb and Optimally Imperfect Decisions." American Economic Review 65 (4), 23-46.

Baumol. William J. and Michael Stewart, 1971. "On the Behavioral Theory of the Firm." In Robin Marris and Adrian Wood (eds.), The Corporate Economy: Growth, Competition and Innovative Potential. London: Macmillan, 68-111.

Edgren, Gösta, Karl-Olof Faxén and Clas-Erik Odhner, 1973. Wage Formation and the Economy. London: George Allen \& Unwin.

Eliasson, Gunnar, 1984, "Micro Heterogeneity of Firms and the Stability of Industrial Growth." Journal of Economic Behavior \& Organization 5 (3-4), 249-274.

Eliasson, Gunnar, 1991," Modeling the Experimentally Organized Economy Complex Dynamics in an Empirical Micro-Macro Model of Endogenous Economic Growth.” Journal of Economic Behavior \& Economic Organization 16 (1), 153-182.

Glancey, Keith S. and Ronald W. McQuaid, 2000. Entrepreneurial Economics. Palgrave: New York.

Helpman, E. (1992), "Endogenous Macroeconomic Growth Theory.” European Economic Review 36 (2), $237-$ 267.

Henrekson, Magnus and Nathan Rosenberg, 2001. "Designing Efficient Institutions for Science-Based Entrepreneurship: Lessons from the US and Sweden.” Journal of Technology Transfer 26 (2), 207-231.

Holcombe, Randall G., 1997. "Entrepreneurship and Economic Growth." Quarterly Journal of Austrian Economics 1 (2), 45-62.

Holmes, Thomas J. and James A. Schmitz Jr, 2001. "A Gain from Trade: From Unproductive to Productive Entrepreneurship." Journal of Monetary Economics 47 (3), 417-46.

Johansson, Dan, 2003. "The Theoretical Firm Is Still Entrepreneurless: A Systematic Examination of Economics Text Books at the Graduate Level." Mimeo. The Ratio Institute, Stockholm.

North, Douglass C. (1990), Institutions, Institutional Change, and Economic Performance. New York: Cambridge University Press.

Oates, Mary I. and William J Baumol, 1972. "On the Economics of the Theatre in Renaissance London." Swedish Journal of Economics 74 (1), 136-160.

Menger, Carl, 1871, Grundsätze der Volkwirtschaftlehre. Wien: Wilhelm Baumüler. 
Rosen, Sherwin, 1997, "Austrian and Neoclassical Economics: Any Gains From Trade?" Journal of Economic Perspectives 11 (4), 139-152.

Scherer, Frederic M., 1980, Industrial Market Structure and Economic Performance. Chicago: Rand McNally. Schwarz, Marius and Robert J. Reynolds, 1983. "Contestable Markets: An Uprising in the Theory of Industry Structure: Comment." American Economic Review 73 (3), 488-490.

Spence, Michael, 1983, "Reviewing Contestable Markets and the Theory of Industry Structure." Journal of Economic Literature 21 (3), 981-990.

Shepherd, William G., 1984, " Contestability vs. Competition.” American Economic Review 74 (4), $572-587$.

Swedberg, Richard, 2000. Entrepreneurship: The Social Science View. Oxford: Oxford University Press.

Wicksell, Knut, 1923, ”Realkapital och Kapitalränta." Ekonomisk Tidskrift 25 (5-6): 145-182.

Åkerman, Gustav, 1921, ’Inflation, Penningmängd och Ränta.” Ekonomisk Tidskrift 23 (9), 143-162.

Åkerman, Gustav, 1923, Realkapital und Kapitalzin. Stockholm 